\title{
The Oral Tradition as a Source of Learning the Local History of South Sumatera
}

\author{
Farida RWD. \\ Sriwijaya Univeristy \\ Inderalaya, Indonesia \\ nasya.afif@gmail.com \\ Nanda Julian Utama \\ Sriwijaya University \\ Inderalaya, Indonesia \\ nandajulian18@gmail.com
}

\author{
Rosmaida Sinaga \\ State University of Medan \\ Medan, Indonesia
}

\begin{abstract}
This article will discuss about oral tradition in some areas in South Sumatra. The main problem in this study is how to make oral tradition as a source of data from relevant and valid historical studies.Oral tradition is one of the most valuable cultural heritages owned by Indonesian people. Indonesian people constitute an integrative and cultural institution among society through oral tradition because they have strong memory in preserving something related oral traditions. Meanwhile, other nations commonly preserve in written inheritance.Lack of written resources to explore the historical culture and various forms of cultural expression make it difficult for people to write about history especially in the sphere of locality. However, to explore the emerging field of oral tradition and various forms of cultural expression in the study shaped by education as well by the writing of history can also come from several oral traditions, of course with some criteria so that the data can be obtained more academically. South Sumatra has wealth of oral traditions, such as Guritan (folk poetry) from Lahat Regency and surrounding areas, Senjang from MusiBanyuasin Regency, Tembang Batanghari Sembilan (folksongs) from Muara Enim Regency, Poetry from Palembang, and some folklore, and many others. Oral tradition contains moral values, customs, religious teachings, arts, history, and so on. However, could it be appreciated as credible historical information and recognized as an alternative tool and technique to document and interpret the past history and culture tradition in South Sumatra? This article seeks to explore the other side of oral tradition especially in South Sumatra, so it can be used as relevant source and useful in learning history. This study used qualitative research with the ethnographic approach related to previewing studies about oral tradition.
\end{abstract} History

Keywords - Oral Tradition, South Sumatra, Data, Learning

\section{INTRODUCTION}

Historical studies related to South Sumatra regions have not received much attention, especially for local historians, limited products of historical studies generated are generally written by none historian researchers. In fact, this region has abundant of diverse history. Only Popular historical themes become the attention of historians and writers of history in the local sphere of South Sumatra. This region had been politically the center of Sriwijaya Kingdom reign, Kingdom, and Sultanate of Palembang, Dutch Colonial Government, Japanese Colonial Government. Thus, a large number of sources had been written about the history of South Sumatera.

Written documents become very important sources in a historical writing. Especially, the primary sources published according to the time of the event to be studied. In Europe, in the 19th century, a famous German historian Leopold Van Ranke says that "no document, no history". No document, there is no history, Ranke claims that in the modern world, the elements of myth in a historical source should be reduced. In addition, Ranke further states that a historical essay is very subjective. Ranke proved his remarks by writing a lot of history with objects about government and dynasties. This writing is clearly very consistent with the use of archival sources [1].

What Ranke had done was something highly recommended in the writing of history. As a science, obviously, a history must be consistent with the "tools of science" respected. However, Ranke disclaimed the important souls of times to be written by a historian writer. Related to Indonesia, the tradition of writing has not been shining as in Europe, America and other regions of the world, which have advanced literacy. Moreover, connected to the effort in exploring local histories, the main obstacle is the limited written sources (mostly in oral sources both oral tradition and oral history). Oral traditions might the only access to get information to be written in history [2].

There is plenty of information from oral tradition that can be used for historical research purposes. But like any other sources, this type of source cannot stand alone, it needs testing, and interpretation, whether oral speech passed on from time to time, contains historical information. The article also attempts to study the various oral traditions of South Sumatra that have potential to historical data. The main question to be discussed is whether the oral tradition of South Sumatra can be used as a source of history? And how to apply it in well organized 
research method? To answer the research questions, this paper uses several relevant sources related to the use of oral tradition as a historical source, including some examples of oral traditions from South Sumatra that can be interpreted as a source of history.

\section{METHODS}

History is a science that has empirical characters, which means that writings in history can be verified. There are several stages commonly conducted in a historical study: heuristic, criticism, interpretation, and historiography [3]. Each stage in writing history is important, and not separated from each other. Heuristics or data collection is the first stage and has relevance to this article.

There are several sources or data categorizations that can be used in a historical study. Among the historians, the categorization is divided into primary and secondary data. The primary data considered as the primary written source or created according to the time of the historical event, such as archives, reports, official records, oral testimonies, contemporary accounts, and so on. While the secondary data is likely to be data or information obtained from previews research such as books, journals, latest journalistic information, and others.

Regarding data sources or data categorizations, what is the position of oral tradition in historiography? Oral traditions are those recollections of the past, orally transmitted and recounted, that arise naturally within and from the dynamics of a culture. The oral tradition itself is a verbal message that tells many things (not just an event or social class) at least pass one generation [4]. Oral tradition and oral history share a common oral nature. While it is deceptively easy to propose distinctions between them, oral history is spoken by people who experience directly a historical past event. Therefore, at the level of its own time, at least the oldest spoken historians are experiencing an event between 60-90 years ago if calculated from this year. Thus, based on the Vansina above, at least an oral tradition is spoken in one generation, hence the recording of a historical event can be much older found in an oral tradition.

Oral traditions have several types and forms, and most are identical to art works like literary works. Common oral tradition often heard by the Indonesian people are pantun (Malay poetic form), folklore, guritan, folklsong, poetry, and others. In the oral tradition, significantly influence the ways we understand and interpret is an attempt to teach or inherit a knowledge to the next generation through oral tradition obtained. Unfortunately, some of the oral traditions contain more about rhetoric than a fact [5]. However, it does not mean that an oral tradition cannot be used as a source of history. A historian who will use the oral tradition as a source must be sensitive to the interpretation of the source obtained. Personally or collectively an oral tradition has a sequential story, describing usual past events about certain conditions in a society, containing moral values, and so on. However, an oral tradition should be tested for its credibility by comparing it with other sources. Ref [6] conducted research on the history of Buton in the 18th century, using oral traditions of the Butonese people of Kabanti, Kabanti is a kind of Buton community poetry. Kabanti contains various information how the people of Buton interpret the events occurred in the 18th century in the form of poems.

\section{RESULT AND DISCUSSION}

South Sumatra is one of the regions in Indonesia that has a considerably large number of oral traditions. One of oral tradition from this region is Guritan and Tembang Batang Hari Sembilan as none physical object of cultural heritage by the Ministry of Education and Culture of Indonesian Republic [7]. In addition, the region also has abundant various folklores, poetries, rhymes, poems, and other spreading into regions of South Sumatra. Furthermore, oral traditions also provide a variety of historical information complementing a historical study especially in areas of with no written tradition.

One of them is folklore; some South Sumatra folklores describe the existence of historical information about the original name of a place or a region. Often in the historical tradition in Indonesia, we find it difficult to find literature explanation for a region name, place, or also a government (empire and empire). This information can even be obtained from stories passed down through generations through oral tradition. For example, the original name of Palembang said to be a place inundated in the past (limbang) then so called as Palembang [8]. Related to the historical geographical studies on Palembang, from time to time this region is dominated by waters, especially swamps. In contrast to the folklore from Musi Banyuasin about the original name of Sekayu, taken from the name of a princess who always brings good lucks. Therefore, in order for the princess to "transmit the blessings" she gets, this region is so called Sekayu [9].

Some oral traditions of folklore from South Sumatra also tell the events related to the legendary Lanun (pirate) in this region. One of them is in the story of Rio Ngonang from Pangkalan Balai (now the capital of Banyuasin Regency, which is a fraction of Musi Banyuasin Regency). In this story mentioned that Rio Ngonang was the son of a beautiful woman named MS. Rubiah Sari Mendung who was thrown from his village because of pregnant without a husband, because it is considered a disgrace. Ms. Rubiah sari Mendung was accommodated in a special place along with other women who had no husband but had a baby. The son who was born by Ms. Rubiah Sari turned out to be different when compared to the other babies because the boy beamed a light. As the result, the sultan of Palembang gave more attention and requested the mother to educate him well.

When the boy was growing adult, the sultan heard that Ms. Rubiah Sari Mendung's hometown was confronted with a stressful condition due to often attacked by Lanun. To overcome this condition, the sultan agreed to send a young man, son of Ms. Rubiah Sari Mendung named Ngonang to combat the criminals, and the attempt was successful. Since then he was appointed as the local ruler by the name of Rio Ngonang (Rio derived from Riyemeant the head of Village).

The folklore above describes the condition of one of the river-maritime community in South Sumatra. As a region known as Batanghari Sembilan (Musi River, Klingi River, Bliti River, Lakitan River, Rawas River, Rupit River, Batang Ari 
Leko River, Ogan River and Komering River) [10], All the streams flow down to the Musi River. In addition, the region is s also fed by thousands of small tributaries spread almost along the region of South Sumatra. Before the road was developed in the early 20th century, the river was the vein of various aspects of community life in South Sumatra. That was why; life around the river flow became very important. In fact, almost every village in South Sumatra followed a river flow pattern [11].

In addition, the above folklore, the Lanun, is part of the very important historical information provided. Bangka Strait and three lanes (Banyuasin, Musi, and Upang) on the eastern coast of South Sumatra are estuaries that become a favorite location for the Lanunto escape after looting their prey in Bangka Strait and its surrounding areas. The existence of Lanun has existed since the reign of Sriwijaya Kingdom [12]. Based on interviews with Mr. Sofian [13] piracy conducted by Lanun is still ongoing until now, and the safest place to escape and disappear is among the three estuaries above.

The existence of the lanun since the past was very disturbing trade centered entirely on the rivers in South Sumatra. But the lanuns were eagerly disturbing around Uluan (upstream) area and the Bangka Strait because of the territory of Palembang relatively safeguard. Due to afraid of Lanun, intermediary traders, especially Chinese traders, were generally reluctant to go through Uluan, they just wait inland traders bringing their commodities in the capital of Palembang. This Conditions continued until the 19th century. Fear of Lanun was very reasonable, given the strength of fleet and pirate troops reached about 700 people [14].

There is also an oral tradition called oral history tells about the fighting spirit in warfare. This poem entitled "Spirit of Struggle" which comes from Lahat regency using local language. Here is an excerpt of oral tradition on the 15th stanza [15].

Ncakaghlukak mbunuh banyak

Mencari jalan membunuh banyak

Finding a way to kill enemies

Inilah die pemude Batak

Inilah dia pemuda Batak

Here we are Batak's youth

Pacak kuntau pacak cekak

Kita dapat bertarung dan melawan

We can fight and againts

Cekow limbow di Padang Karit

Hiruk pikuk di Padang Karet

Such Frenzy in Rubber plants

Tiap simpanganlah betunggu

Tiap simpang sudah berjaga

Guarding in every intersection

Becagakan senjate berat

Berlarik senjata berat

Weighing with heavy weapons

Lah belage pule rurahini

Sudah bertempur pula daerah ini

so fighting in this area

Karene Belande pecah due

Karena Belanda pecah dua

Because the Dutch separated
Kutelah njadiluk lubuk lukluang

Daerah pertahanan menjadi seram

Defense area becomes frightening

Kere baimintak tulung pekikkah

Ibu-ibu minta tolong dipekikkan

Women shout for help

Dak keciklah sengkiap gale

Anak-anak sudah ketakutan semua

The children be scared

Sekulah tutup gale

Sekolah tutup pula

Schools were closed

Cine bedagang tutup gale

Cina berdagang tutups emua (Mukmin, 2017: 10)

Chinese closes their trade

Bait 17, sumadiin Mukmin, 11)

Lah macam-macam pendengaghan

Sudah macam-macam pendengaran

we have listened all sorts

Sikat ndenggesitlah luke dikit

Tiap yang mengaduh sudah luka sedikit

those complains slightly injured

Sikatn dengeghamlah luke dalam

Tiap yang mengeram sudah luka dalam

Those groans will be wounded

Ade pule nikte tundukluk luke tukuk

Ada pula yang tertunduk luka kuduk

A bowed head made some wound

Sikat ndangegerihingkahmatilah

Tiap yang menggigil menjelang ajal

those shivering is about to death

Mabktulahmintak garam

Seperti itulah minta garam

That's what salt is for

Mbaktulahn jejak gaung

Seperti itulah menjejak gaung

That's what stepping up the echo

Masihgi sempat sampaika pesan

Masih sempat menyampaikan pesan

Still had time to deliver the message

Wahai kance due duduklah kudai

Wahai teman berdua duduklah dahulu

$\mathrm{O}$ two friends sit down awhile

Aningikudai pesanku ini

Dengarkan dahulu pesanku ini

listen to my message

Nduknga bapak cengki nangis

Ibudan ayah tentu menangis

parents must be moan crying

Didemustahil bapakkah pingsan

Tidak mustahil ayah akan pingsan

father will faint indeed

Binikahngejut jande mude

Istri akantiba-tiba menjadi janda

Wife will suddenly become a widow

The oral tradition relating to the struggle against the invaders seemingly tells only about the struggle during the 
Physical Revolution around 1945-1949. Nevertheless, it could have been entrenched long before, since the people of Besemah (Pesemah) were well-known for their fighting spirit in defending their territories post-annihilation of the Palembang Sultanate (1825). Even though the resistance of the central government in Palembang had ended, but some resistance in the Uluan regions, especially around Pasemah, still often fought against the Dutch Colonial government until 1866 [16].

In addition to the oral tradition of South Sumatra, there are also various oral historical traditions that are inherited besides the works mentioned.Some oral traditions may also an event that has been perpetuated from the past until now. For example about the marriage customs existing in this region, which is said to have existed since hundreds of years ago. In the wedding ceremony is commonly used local custom, information and the custom used commonly obtained from people who understand the custom itself, and in heritage to the next generation.It is supposed to be a kind of code of ethics in the local marriage custom, therefore anyone who wants to marry should consult with the elderly who understand the marriage custom ceremony. As long as the marriage custom is still carried on traditions concerning the marriage custom ceremony.It then an oral tradition still continues.

\section{CONCLUSION}

Utilizing oral tradition as a source of history is not impossible. Oral tradition as subject deals with the study of significant past events is only transmitted through the efforts of witnesses to the events. In this region where the vast majority of Indonesian people are oral history speakers, oral traditions provide information about things that happened in the past that were not recorded by written sources. Therefore, the oral tradition should be a pride for Indonesian who can preserve their history until now. However, the use of oral tradition as historical data must also be followed by the awareness of history writers in understanding the oral tradition and the contexts of the times which he will discuss.

South Sumatra, which has a wealth of oral traditions, is actually a vacant lot that has not been worked on by historians. In fact, The customary archival role of the custodian or keeper of local, state, and central government records has had to be modified and transformed in many ways it is used properly, then a lot of historical information can be absorbed as a collection of historiography about this region.There are many folklores that can be used as a reference to see the condition of past events, such as pirate story which demonstrates South Sumatra as a waters region. In addition, rhyme and poetry which are representations of past event that may exist when the author is still alive can also be used as a reference. In conclusion, the oral tradition in a region can basically be used as a source of history, but its use should still be verified with other supporting sources so that the data obtained valid and relevant.

\section{REFERENCES}

[1] Anna Green \& Kathleen Troup, The Houses of History, New York: New York University Press, 1999, pp: 1-3.
[2] Abdullah, Taufik (ed.).1985.Sejarah Lokal di Indonesia. Yogyakarta: Gadjah Mada University Press.

[3] Helius Sjamsudiin, Metodologi Sejarah, Yogyakarta: Ombak, 2007.

[4] Jan Vansina, Tradisi Lisan Sebagai Sejarah, Yogyakarta: Ombak, 2014.

[5] Depdikbud, Sistem Ekonomi Tradisional Daerah Sumatera Selatan, Jakarta: Depdikbud, 1987.

[6] Susanto Zuhdi, 2010, Labu Rope Labu Wana, Sejarah Buton Yang Terabaikan, Jakarta: Rajawali Press.

[7] Paluseri, et.al, Warisan Budaya Tak Benda Indonesia Panetapan Tahun 2014, Jakarta: Kementerian Pendidikan dan Kebudayaan, 2014.

[8] AB. Yass, Cerita Rakyat Sumatera Selatan, Jakarta: Grasindo, 1993, pp: $1-5$

[9] Dinas Pemuda dan Pariwisata Kabupaten Musi Banyuasin, Cerita Rakyat Muba, Sekayu: PemerintahKabupatenMusiBanyuasin, 2010, pp: 39-43.

[10]P. Roo De Faille, Dari ZamanKesultanan Palembang, Jakarta: Bhratara.

[11]Purwanto, Bambang, The Economic Integration of Different Ecological Zones in Southern Sumatra in Late Colonial Period, Yogyakarta: Jurnal Humaniora no. 7 (1998).

[12]Prof. Liang Liji, Dari Relasi Upeti ke Mitra Strategis, 2000 Tahun Perjalanan Hubungan Tiongkok-Indonesia, Jakarta: Kompas, pp: 260262.

[13] Interview with Mr. Sofian, September $6^{\text {th }} 2013$.

[14] Arsip Nasional Republik Indonesia Java Gouvernement Gazette, July 4, 1812.

[15] Suhardi Mukmin, Guritan Sebagai Media Pendidikan Karakter Bangsa, Orasi Ilmiah pada Upacara Pelepasan Alumni baru FKIP Universitas Sriwijaya, 2017.

[16] Mestika Zed, Kepialangan Politik dan Revolusi di Palembang 1900-1950, Jakarta: LP3ES, 2003,: 48-50. 